\title{
T-Cell Acute Lymphocytic Leukemia Protein 1
}

National Cancer Institute

\section{Source}

National Cancer Institute. T-Cell Acute Lymphocytic Leukemia Protein 1. NCI Thesaurus. Code 17418

T-cell acute lymphocytic leukemia protein 1 (331 aa, $~ 34 \mathrm{kDa}$ ) is encoded by the human TAL1 gene. This protein plays a role in transcriptional regulation and hematopoiesis. 